\title{
GENERALIZATION AND CHARTOMETRIC ANALYSIS OF THE SITNICA RIVER NETWORK SYSTEM
}

\author{
BOJANA JANDŽIKOVIĆ1 ${ }^{\text {* }}$ \\ ${ }^{1}$ Faculty of Natural Sciences and Mathematics, University of Priština, Kosovska Mitrovica, Serbia
}

\begin{abstract}
The basin of Sitnica river represents a good option for chartometric investigation. In modern hydrology, digital and GIS analyses play very important role today. In this research we were able to obtain the main properties of the river basin and river network with the help of digital line generalization. The results from the two kind of maps with two scales 1:25.000 and 1:50.000 showed differences in length of the main river Sitnica and its tributaries. These differences may be included into the analysis of the Sitnica river network. For the first time it was concluded that the Sitnica river has bi-polar dendritic parallel network. The $80 \%$ of right tributaries have angles between $2^{\circ}$ and $5^{\circ}$ degrees in direction of the Sitnica river. The left tributaries have angles between $1^{\circ}$ and $2^{\circ}$ degrees with the main water-course.
\end{abstract}

\section{Keywords: Sitnica, River network, Generalization, GIS, Remote Sensing, Chartometric method.}

\section{INTRODUCTION}

Cartographic generalization has five main concepts. These concepts play main role, especially in the presentation in the Hydrology science. Hydrology as any other spatial science has the necessity for cartographic visualization and abstraction. The Hydrology analysis of the river network system must be used in any complete analysis of watershed. The main algorithms in the analogue generalization are classification, simplification, exaggeration, symbolization and induction (Arnhiem, 1976; Bertin, 1983).

Land waters includes rivers, water streams, lakes, swamps, etc. A river which is presented on a particular map surface joined with river systems represent the river network on a territory.

A chartometric and network analysis must contain two elements. These are length and width of the river. These data presented on the maps would be very important for cartographic generalization. For the rivers presented on the maps as lines, two kinds of generalization are very important. The first is classification and the second is simplification.

The goal of classification on the maps is to express the salient character of a distribution. Classification presents ordering and scaling as well as grouping of features according to their attributes (Douglas \& Peucker, 1973; Szyperski \& Murer, 2002).

Also, the classification presents an intellectual process that will group very similar features in good order. There are two common ways of performing classification on the maps. The first is allocation of similar qualitative attributes, like land use or river networks. After that quantitative attribute values may be transformed into numerically defined groups. The second is attribute value at a selected location to create a typical feature on the maps. Usually, the classification includes class interval

\footnotetext{
* Corresponding author: bojana.jandzikovic @ pr.ac.rs GEOGRAPHY, GEOSCIENCE AND ASTRONOMY
}

selection and various routines. One important manipulation in this process is called clustering. Clustering is necessary when numerous discrete and concrete features characterize the distribution and it reduces the map scale for more than 50\%. The simplification must reduce the amount of information to the map ability and legibility (Court, 1966). The essential geographical characteristics of the mapped phenomena will be presented to show hydrology properties.

The map space available to portray selected features is a functional scale. The map scale, i.e. ratio must be reduced by the square of the difference in linear scale. The reducing of scale by one-half, rather than three-halves reduces the map area to onequarter. For example, a territory mapped at 1:50.000 scale will only occupy one-fourth of a map space when mapped at 1:100.000. But, the most important law for cartographic line generalization is called Topfer Radiallaw (Topfer \& Pilliwizer, 1996). On applying this radical law, it is possible to determine the number of items to be expected on the new complied map. For the purpose of this research we used this law and GIS chartometric analysis in hope of better understanding the Sitnica drainage river network. Upon establishing the Topfer law, it is possible to expect the following algorithms and procedures on the map. We then have generalized sets, such as 1-point features sets; 2-linear features sets; 3-area features sets (Mackaness \& Edwards, 2002; Kraak \& Ormeling, 1996; Petere, 2001; Robinson, 1995).

This radical Topfer law may be implemented into GIS software. The Sitnica rivers flows in the central part of Kosovo. The Sitnica river system occupies the area of $2861 \mathrm{~km} 2$. This river system covers $26 \%$ of the Kosovo and Metohija territory or $35 \%$ of the basin of river Ibar. With its tributaries included, the Sitnica river system covers $22.6 \%$ of the Ibar river system. One of the leading hydrologists Plana claims that the Sitnica springs directly from the river Toplica, and the hydrologist Labus thinks that the Sitnica emerges at the village of Robovac from two 
streams, Sazlija its right tributary, and Stimljanka its left tributary (Labus, 1974; Ivanović et al., 2016). After total chartometric and GIS numerical analysis we derived precise network drainage system of the river Sitnica.

\section{MATERIALS AND METHODS}

\section{GIS multi-criteria analysis}

After determing physical and hydrological charateristics of the river Sitnica basin, we went on to determine the chartometric and drainage network properties (Valjarević et al., 2013). In this investigation we used two kinds of GIS softwares. These softwares are QGIS (Quantum Geographical Information System) and SAGA (System for Automated Geoscientific Analyses).

By using these softwares we have the possibility for georeferencing, digitizing and vectorizing all attributes of the elements of the river. QGIS has the possibility of printing these images on a single sheet of paper in many different formats. The concrete advantage is that QGIS is capable of characterizing and integrating vector and raster data (Harrie \& Weibel, 2007). The software is also capable of creating phase digitalization and vector data. The other tools of the software are supported and generated later in database. The digitally supported generalization has certain advantages in comparison with analogue generalization. The main advantage is in very precise segmental processing algorithms of line river generalization. The final database is presented in two kinds of codes ASCII and PostGIS. We used 16 sheets of the topographic maps in scale 1:25.000. These maps are labeled as Podujevo, Pristina, Kosovska Mitrovica. Software QGIS 2.18.4 was used for digitizing and vectorising maps with two scales 1:25.000 and 1:50.000. Another software SAGA used in this research will be excellent in the estimation of DEM (Digital Elevation Model) and calculating of a watershed. In this software, in order to calculate river network, it is necessary to use the procedures as follows. The first is the method of downloading data from the satellites. In this research Aster global DEM with resolution of $30 \mathrm{~m}$ was used. Today, there are plenty of methods which would be useful in DEM estimation, segregation and calculations (Valjarević et al., 2018a; Abrams, 2010; Schneider et al., 2014; Valjarević et al., 2018b). The analysis of relief conducted by special DEM calculations may be applied onto many areas of geospatial sciences (Milanović et al., 2017; Lukić et al., 2009).

\section{SPECIAL METHODS IN THE RESEARCH}

\section{Topfer's Radical law}

The Topfer's radical law is very important in modern GIS technologies, especially in line segmental generalization. The first equation Eq. (1) which presents the relationship between map scale and number of items on the map is:

$$
\mathrm{n}_{\mathrm{c}}=\mathrm{n}_{\mathrm{s}} \sqrt{\frac{\mathrm{S}_{\mathrm{c}}}{\mathrm{S}_{\mathrm{s}}}}
$$

Where;

$\mathrm{n}_{\mathrm{C}}$-presents the number of items on a derived map with a scale fraction (ratio) of $\mathrm{S}_{\mathrm{c}}$,

$\mathrm{n}_{\mathrm{c}}$-presents the number of items on a source (original) map with a scale fraction (ratio) of $\mathrm{S}_{\mathrm{S}}$.

The main problem of simplification in the process of generalization is the nature of the source data. For example, features of islands or swamps are generally presented without process of exaggeration. On the other hand, items like industry objects for example, with their associated names, take up a much larger proportion of space, and may be retained. Due to everything listed before, it is necessary to introduce two uniform constant, $\mathrm{C}_{\mathrm{e}}$ and $\mathrm{C}_{\mathrm{i}}$ into radical law. The next Eq. 2 describes this postulate:

$$
n_{c}=n_{s} C_{e} C_{f} \sqrt{\frac{S_{c}}{S_{s}}}
$$

$\mathrm{C}_{\mathrm{e}}$-presents the constant of symbolic exaggeration and has three forms:

$\mathrm{C}_{\mathrm{e} 1}$-presents normal symbolization or elements on the maps appearing without exaggeration.

$\mathrm{C}_{\mathrm{e} 2}=\sqrt{\frac{\mathrm{S}_{\mathrm{S}}}{\mathrm{S}_{\mathrm{c}}}}$ presents feature of areal extent on the map, shown in outline, without exaggeration, like lakes and swamps.

$\mathrm{C}_{\mathrm{e} 3}=\sqrt{\frac{\mathrm{S}_{c}}{\mathrm{~S}_{s}}}$ presents symbolization involving great exaggeration of the area on the map or required on the complied map,

$\mathrm{C}_{\mathrm{e} 3}$ presents constant of symbolic form and also has three types: $\mathrm{C}_{\mathrm{f} 1}=1.0$ presents symbols or features complied without essential change,

$\mathrm{C}_{\mathrm{f} 2}=\frac{\omega_{s}}{\omega_{c}} \sqrt{\frac{S_{s}}{S_{c}}}$ was taken for linear symbols (rivers), which line widths on the source map $\omega_{S}$ and the newly derived map $\omega_{C}$ are the main items in generalization.

$\mathrm{C}_{\mathrm{f} 3}=\frac{a_{s}}{a_{c}} \sqrt{\frac{S_{c}}{S_{s}}}$ presents relation for area symbols in which the areas of the symbols on the source map $\alpha_{C}$ and the newly derived map $\alpha_{C}$ are the important items in the process of generalization. The equation 2 presents the most important relation in the process and procedures of line generalization. Line generalization in our case was very accurate, since scale of the maps is $1: 25.000$ and 1:50.000. 


\section{GIS algorithms used in this research}

GIS and calculation of data and their modelling in combination with algorithms of line generalization are very powerful tools for calculating properties of a river drainage network and network basin (Wu \& Chen, 2016). The river basin of the river Sitnica presents one interesting territory for GIS analysis and calculations. The raster data with a very precise resolution of $30 \mathrm{~m}$, were downloaded and converted into universal projection UTM as well as WGS84 ellipsoid. With the help of two types of software QGIS and SAGA we also determined the properties of watershed and river drainage network. In analyzing the Sitnica river basin, we used printed topographic maps from different periods (1953, 1977, and 1987) with the two scales $(1: 25.000 ; 1: 50.000)$. After digitization and vectorization, we obtained digitized maps. In this process of digitization, we used the open-source software QGIS and SAGA. High-resolution data from 2013, with a grid of $10 \times 10$ pixels at $30 \mathrm{~m}$ resolution, were downloaded from USGS (United States Geological Survey) and from the official web page Earth Explorer - LAND SAT (http://earthexplorer.usgs.gov/). GIS analysis in combination with numerical methods is very powerful tool for calculating drainage network properties. The process of DEM and basic relief analysis in an area provides letter manipulation in GIS software. Although there are many other methods, the priority is given to 3D modelling and watershed analysis (Valjarević et al., 2018c).

\section{RESULTS}

The drainage system of the Sitnica river shows the following characteristics. The south-east basin has an average slope of $7.8^{\circ}$, the north-east has $4.4^{\circ}$, whereas the south part has $4.3^{\circ}$. The minimum altitude in the basin is $159 \mathrm{~m}$, the maximum is $1767 \mathrm{~m}$. The average altitude is $480 \mathrm{~m}$. The total number of tributaries according to the scale of 1:25.000 is 92, and according to a scale of 1:50.000, it is 91 . Some of the biggest tributaries in the Sitinica river network are the Drenica with $41.1 \mathrm{~km}$ of length in scale 1:25.000, in scale 1:50.000 is $41.0 \mathrm{~km}$, the Vrbica length in scale $1: 25.000$ is 24.1 and in scale $1: 50.000$ is 25.0. The Žegovka with length of $22.3 \mathrm{~km}$ in scale $1: 25.000$ and with length of $23.0 \mathrm{~km}$ in scale 1:50.000. The Prištevka with length of $19.9 \mathrm{~km}$ in scale 1:25.000 and with length of $20.0 \mathrm{~km}$ in scale 1:50.000. The Janjevka with length of $16.0 \mathrm{~km}$ in scale 1:50.000 and $16.5 \mathrm{~km}$ in scale 1:25.000. The Gračanka $17.0 \mathrm{~km}$ of length in scale 1:50.000 and $16.9 \mathrm{~km}$ of length in scale 1:25.000. The Prištevka with length of $20.0 \mathrm{~km}$ in scale 1:50.000 with length of $19.9 \mathrm{~km}$. The Lab with length in scale 1:25.000 of $57.0 \mathrm{~km}$ and with length of $59.1 \mathrm{~km}$ in scale 1:50.000. The Batlava with length of $20 \mathrm{~km}$ in scale 1:25.000 and with length of $20.2 \mathrm{in}$ scale 1:50.000. The Dubnička with length of $24.0 \mathrm{~km}$ in scale $1: 25.000$ and with length of $22.1 \mathrm{~km}$ in scale 1:50.000. The Bredaška with length of $14 \mathrm{~km}$ in scale 1:25.000 and with length of $14,4 \mathrm{~km}$. The Kačandolska with length of $30.0 \mathrm{~km}$ in scale $1: 25.000$ and with length of $29.1 \mathrm{~km}$ in scale 1:50.000. The Crvena with length of $15.0 \mathrm{~km}$ in scale 1:25.000 and with length of $15.9 \mathrm{~km}$ in scale 1:50.000. The Slatina with length of $10 \mathrm{~km}$ in scale 1:25.000 and with length of $10.6 \mathrm{~km}$ in scale 1:50.000. The Margulska with length of $17.0 \mathrm{~km}$ in scale 1:25.000 and with length of $17.5 \mathrm{~km}$ in scale 1:50.000. After chartometric method supported with GIS and remote sensing analysis we concluded that $70 \%$ of the rivers in the Sitnica network are right tributaries and $30 \%$ are left tributaries (Figure 1). The errors in the segmental line digital generalization are presented in the (Table 1). The $80 \%$ of right tributaries have angles between $2^{\circ}$ and $5^{\circ}$ degrees in direction with the Sitnica river. The left tributaries have angles between $1^{\circ}$ and $2^{\circ}$ degrees with the main watercourse.

Table 1. The Sitnica river network, presenting some of its rivers with included error of generalization in $\%$.

\begin{tabular}{|c|c|c|c|}
\hline Name & $\begin{array}{l}\text { Position } \\
\text { tributary }\end{array}$ & of $\quad 1: 25.000$ & $1: 50.000$ \\
\hline Drenica & Left & $0.5 \%$ & $0.9 \%$ \\
\hline Vrbica & Right & $0.4 \%$ & $0.8 \%$ \\
\hline Žegovka & Right & $0.3 \%$ & $0.7 \%$ \\
\hline Prištevka & Right & $0.4 \%$ & $0.9 \%$ \\
\hline Crvena & Right & $0.2 \%$ & $0.8 \%$ \\
\hline Grčanka & Right & $0.5 \%$ & $1.0 \%$ \\
\hline Batlava & Left & $0.3 \%$ & $0.8 \%$ \\
\hline Dubnička & Left & $0.2 \%$ & $0.9 \%$ \\
\hline Bradeška & Left & $0.2 \%$ & $0.8 \%$ \\
\hline Kačandolska & Right & $0.4 \%$ & $0.9 \%$ \\
\hline Slatina & Left & $0.5 \%$ & $1.0 \%$ \\
\hline
\end{tabular}

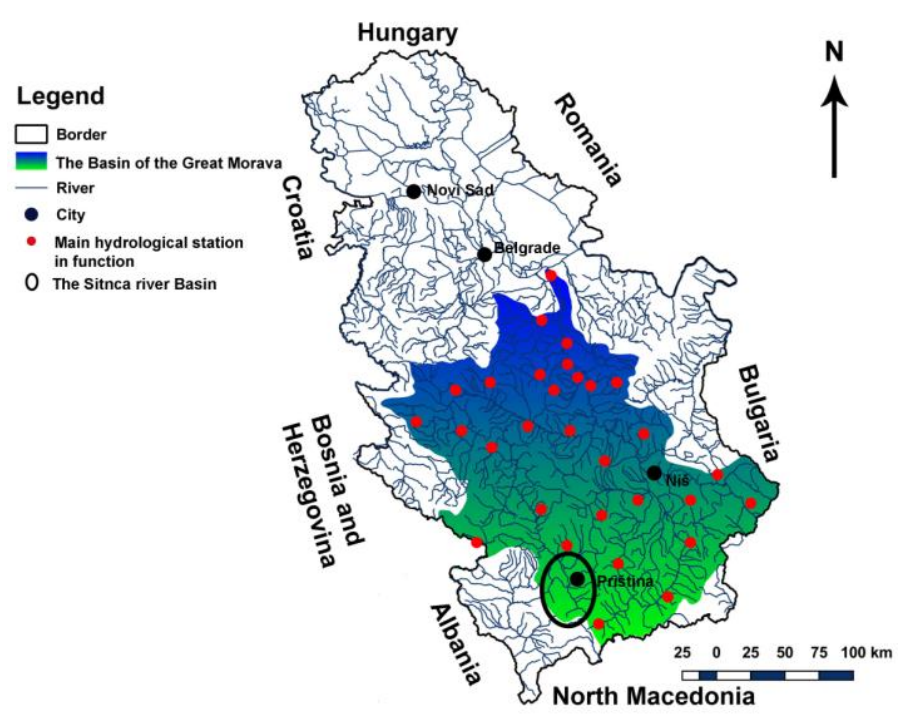

Figure 1. The basin of Sitnica river and the river network of Serbia.

According to the results from the Table 1, we concluded that rivers with meanders have higher volume of line 
generalization a Rivers with five or less meanders have smaller volume of line generalization, being less than $0.5 \%$ (Figure 2).

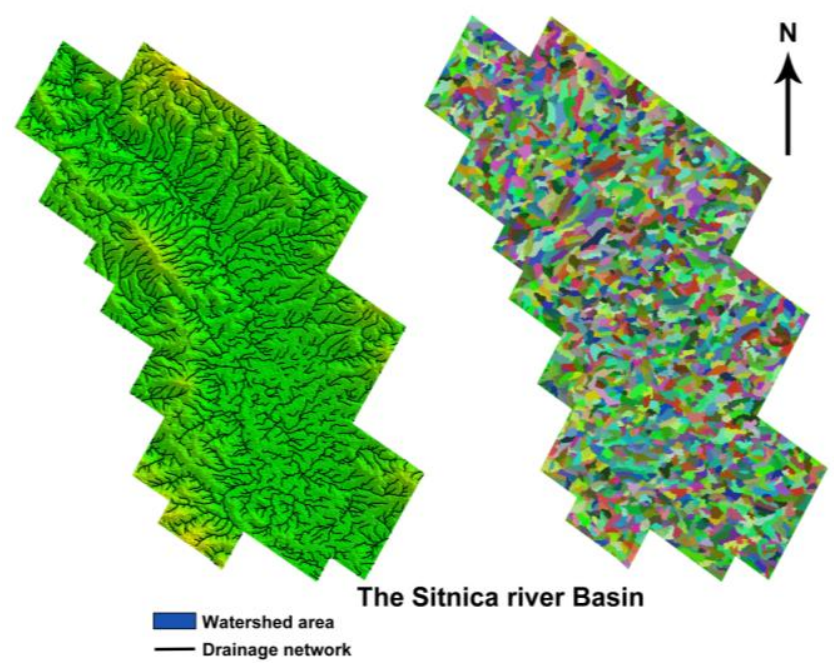

Figure 2. Generalized Sitnica river basin with drainage network and watershed areas.

\section{CONCLUSION}

With the help of two types of software, QGIS and SAGA results of line generalization were satisfactory. The line generalization supported by GIS and remote sensing methods gave very interesting results in hydrological research The river basin and the river network present two most important features of a river's hydrography. In this research, we used the Sitnica river basin, because of its interesting geographical position, separating two main parts of Kosovo. The river Sitnica presents the part of small Kosovo. Line generalization with chartometric methods in this research led to some conclusions. The first is: When we have doubled scale, the generalization grows for $5 \%$. The error in generalization at two scales 1:25.000 and 1:50.000, at the length of $1 \mathrm{~km}$ of the Sitnica was $0.02 \%$, and $0.05 \%$ respectively. The rivers with five or more meanders have higher volume of generalization on digital and analogue maps. After total GIS and chartometric analysis we came to a conclusion that the Sitnica river has bi-polar dendritic drainage patterns and parallel network.

\section{ACKNOWLEGMENTS}

I would like to express my gratitude to the professor Blagoja Markoski, who was so kind to provide some of the data used for the purpose of this research.

\section{REFERENCES}

Abrams, M. 2000. The Advanced Spaceborne Thermal Emission and Reflection Radiometer (ASTER): Data products for the high spatial resolution imager on NASA's Terra platform. International Journal of Remote Sensing, 21(5), pp. 847-859. doi:10.1080/014311600210326

Arnheim, R. 1976. The Perception of Maps. The American Cartographer, $3(1), \quad$ pp. $\quad$ 5-10. doi:10.1559/152304076784080276

Bertin, J. 1983. Semiology of Graphics: Diagrams, Networks, Maps. University of Wisconsin Press.

Brunner, F. 1997. Continuous Monitoring of Deformations using the Global Positioning System. AvH-Magazine, 69.

Court, A. 1966. The Inter-Neighbor Interval. Yearbook of the Association of Pacific Coast Geographers, 28(1), pp. 180182. doi:10.1353/pcg.1966.0005

Douglas, D., \& Peucker, T. 1973. Algorithms for the Reduction of the Number of Points Required to Represent a Digitized Line or its Caricature. Canadian Cartography, 10, pp. 111122.

Harrie, L., \& Weibel, R. 2007. Modelling the Overall Process of Generalisation. In W. A. Mackaness, A. Ruas, \& L. T. Sarjakoski Eds., Generalisation of Geographic Information.Elsevier BV., pp. 67-87. doi:10.1016/b978008045374-3/50006-5

Ivanović, R., Valjarević, A., Vukoičić, D., \& Radovanović, D. 2016. Climatic regions of Kosovo and Metohija. The University Thought - Publication in Natural Sciences, 6(1), pp. 49-54. doi:10.5937/univtho6-10409

Jun, C., Ban, Y., \& Li, S. 2014. China: Open access to Earth land-cover map. Nature, 514(7523), pp. 434-434 doi: $10.1038 / 514434 \mathrm{c}$

Kraak, M. J., \& Ormeling, F. J. 1996. Cartography: Visualization of spatial data. London: Longman.

Labus, D. 1974. Hydrological regions in Kosovo. In Collecting paper of the University of Pristina. Pristina. pp. 123-140.

Lukić, T., Marković, S. B., Stevens, T., Vasiljević, D. A., Machalett, B., Milojković, N., Basarin, B., \& Obreht, I. 2009. The Loess "Cave" Near the Village of Surduk: An Unusual Pseudokarst Landform in the Loess of Vojvodina, Serbia. Acta Carsologica, 38(2-3). doi:10.3986/ac.v38i23.124

Mackaness, W., \& Edwards, G. 2002. The Importance of The Modelling Pattern and Structure in Automated Map Generalization. In Proceeding of the Joint Workshop on Multi-Scale Representations of Spatial Data. Ottawa. pp. 1243-1249.

Milanović, M., Tomić, M., Perović, V., Radovanović, M., Mukherjee, S., Jakšić, D., Petrović, M., \& Radovanović, A. 2017. Land degradation analysis of mine-impacted zone of Kolubara in Serbia. Environmental Earth Sciences, 76(16). doi:10.1007/s12665-017-6896-y

Petere, B. 2001. Measure for the Generalization of Polygonal Maps with Categorical Data. In Fourth ICA Workshop on Progress in Automated Map Generalization, Bejing.

Robinson, H. A. 1995. Elements of Cartography.New York: John Wiley and Sons, Inc.

Schneider, U., Becker, A., Finger, P., Meyer-Christoffer, A., Ziese, M., \& Rudolf, B. 2014. GPCC's new land surface precipitation climatology based on quality-controlled in situ data and its role in quantifying the global water cycle. Theoretical and Applied Climatology, 115(1-2), pp. 15-40. doi:10.1007/s00704-013-0860-x 
Szyperski, C., \& Murer, D. 2002. Component Software.Addison Waslay. pp. 123-129; 2nd Edition.

Topfer, F., \& Pilliwizer, W. 1996. The Principles of Selections. Cartography Journal, 3, pp. 10-16.

Valjarević, A., Živković, D., \& Stevanović, V. 2013. Comparison of an analogue and computer supported line generalisation following the concrete example of the Sitnica River system. Scientific Research and Essays, 8(34), pp. 6371648. doi:10.5897/sre11.1804

Valjarević, A., Srećković-Batoćanin, D., Valjarević, D., \& Matović, V. 2018a. A GIS-based method for analysis of a better utilization of thermal-mineral springs in the municipality of Kursumlija (Serbia). Renewable and Sustainable Energy Reviews, 92, pp. 948-957. doi:10.1016/j.rser.2018.05.005
Valjarević, A., Djekić, T., Stevanović, V., Ivanović, R., \& Jandziković, B. 2018b. GIS numerical and remote sensing analyses of forest changes in the Toplica region for the period of 1953-2013. Applied Geography, 92, pp. 131-139. doi:10.1016/j.apgeog.2018.01.016

Valjarević, A., \& Živković, D. 2018c. Digital topographic modelling in case with higher flood in the municipality Obrenovac. The University Thought - Publication in Natural Sciences, 8(2), pp. 44-48. doi:10.5937/univtho8-18679

Wu, S., \& Chen, Y. 2016. Examining eco-environmental changes at major recreational sites in Kenting National Park in Taiwan by integrating SPOT satellite images and NDVI. Tourism Management, 57, pp. 23-36. doi:10.1016/j.tourman.2016.05.006 